\title{
The application of ergonomics aspect and Kansei engineering in designing communication aid for children with autism
}

\section{Linda Herawati Gunawan* and Markus Hartono}

Department of Industrial Engineering, University of Surabaya,

Jalan Raya Kalirungkut Tenggilis, Surabaya 60293, Indonesia

Email: lindawala@gmail.com

Email: markus@staff.ubaya.ac.id

*Corresponding author

\section{Hany Mustikasari}

Fashion Design and Lifestyle Program, Department of Management Product Design, University of Surabaya, Jalan Raya Kalirungkut Tenggilis, Surabaya 60293, Indonesia Email: hanymustikasari@ymail.com

\begin{abstract}
Autism is a psychological disorder; the symptoms include impairment in verbal and nonverbal communication. The increasing number of children with autism is not followed by the number of inclusion schools and therapists, to the point that there is still a considerable number of autistic children with little access to proper therapy. To address this issue, a communication aid called PECS was designed to help autistic children. PECS is widely used worldwide, including in Indonesia. However, PECS have several drawbacks. This paper attempts to design better PECS media. The selected design of PECS media was $7 \times 7 \mathrm{~cm}$ in size, and made from polypropylene layer pad. The media set was also complemented with aromatherapy oil blend. After being tested with 10 autistic children, it was measured by the time needed to pick the media. It was recorded that the picking time shortened from 48.06 to 41.49 seconds.
\end{abstract}

Keywords: autism; autistic children; communication aid; ergonomics; Kansei engineering; PECS; PECS in Indonesia.

Reference to this paper should be made as follows: Gunawan, L.H., Hartono, M. and Mustikasari, H. (2016) 'The application of ergonomics aspect and Kansei engineering in designing communication aid for children with autism', Int. J. Human Factors and Ergonomics, Vol. 4, No. 1, pp.47-59.

Biographical notes: Linda Herawati Gunawan: She obtained her bachelor's degree in Industrial Engineering from the University of Surabaya and her master's degree in Industrial Engineering from Institute of Technology of Sepuluh Nopember (ITS) in 2001 and 2005, respectively. Her teaching and research interests are in ergonomics (for special needs and populations), engineering design, organisational management and entrepreneurships. She is very active in research and has published her research papers in several national seminars and international conferences. She is a member of Indonesian Ergonomics Society (IES) for 2012-2015. 
Markus Hartono: He is an Assistant Professor at the Department of Industrial Engineering, University of Surabaya, Indonesia. He received his Bachelor of Engineering (B.Eng.) in Industrial Engineering from University of Surabaya (Ubaya), Indonesia, in 2000 with predicate of Cum Laude. In 2004, he received the ASEAN Graduate Scholarships (AGS) award for pursuing his master's degree in Industrial and Systems Engineering from National University of Singapore (NUS), and he obtained his Master of Science (M.Sc.) in 2005. In 2008, he received a prestigious award of NUS Graduate Research Scholarships for 4 years for pursuing his $\mathrm{PhD}$, and obtained his $\mathrm{PhD}$ degree in 2012 . He received Best Paper Award of the 14th Quality in Research (QiR) in 2015. His teaching and research interest is in ergonomics, product design and management, work measurement, time and motion study and industrial applied statistics. He is Vice President of Indonesian Ergonomics Society (IES) 2015-2018.

Hany Mustikasari: She obtained her bachelor's in Visual Communication Design from Petra Christian University in 2004. Her major research and teaching interests are in visual communication design, branding strategy, advertising and fashion and product design.

\section{Introduction}

Autism is one of the disorders which affects a considerable number of children. Its cause is yet to be identified. In 2008, one in every 100 children was affected with autism, and by 2012, the ratio had increased to one in every 88 (Pusponegoro, 2007). However, the number of therapists for autism cases is relatively constant every year. To help parents assist their autistic children at home, picture exchange communication system (PECS) is used. This method, which was first developed in the US (Tanjung and Elina, 2000), aims to train children with special needs to communicate, and particularly to improve their verbal skill. PECS, which employs picture cards, has been very successful in the US (Jennifer, Gidley and Yana, 2014).

This study attempts to design a communication aid to assist autistic children in developing their communication skill. Ergonomics aspect and users' emotion are considered as important factors in the design. From the ergonomics standpoint, the tool design is expected to be user friendly and materially benign for children. Users' emotion is also an important factor since it has been observed that autistic children tend to have mood swings (Micko and Antonia, 2013).

In the preliminary study, an observation was conducted in several autism therapy schools in Surabaya, Indonesia, and it was found that the schools made their own communication aids using paper or laminated paper. These proved difficult for autistic children to use, and in extension, played a significant role in their emotions. On the other hand, therapists had difficulties in finding suitable images mimicking real life applications in Indonesia since PECS was developed in the USA. Other drawbacks related to these are the thin and sharp corners, ease of being damaged, unstandardised size and the lack of anthropometrics consideration.

In general, children with autism are usually characterised by a triad of symptoms: restricted interests, impairment in communication and impairment in social interactions. Upon receiving sensory information, they do not show proper reaction or sometimes even 